Please do not remove this page

RMIT

UNIVERSITY

\title{
TGF-ß stimulates biglycan core protein synthesis but not glycosaminoglycan chain elongation via Akt phosphorylation in vascular smooth muscle
}

Osman, Narin; Getachew, Afework; Burch, Micah; Lancaster, Graeme; Wang, Rikang; Wang, Haitau; Zheng, Wenhua

https://researchrepository.rmit.edu.au/esploro/outputs/9921858241601341/filesAndLinks?institution=61RMIT_INST\&index=null

Osman, N., Getachew, A., Burch, M., Lancaster, G., Wang, R., Wang, H., Zheng, W., \& Little AM, P. (2011). TGF-ß stimulates biglycan core protein synthesis but not glycosaminoglycan chain elongation via Akt phosphorylation in vascular smooth muscle. Growth Factors, 29(5), 203-210.

https://doi.org/10.3109/08977194.2011.615747

Document Version: Accepted Manuscript

Published Version: https://doi.org/10.3109/08977194.2011.615747

Repository homepage: https://researchrepository.rmit.edu.au

(C) 2011 Informa UK, Ltd

Downloaded On 2023/04/26 19:34:56 +1000 
Thank you for downloading this document from the RMIT Research Repository.

The RMIT Research Repository is an open access database showcasing the research outputs of RMIT University researchers.

RMIT Research Repository: http://researchbank.rmit.edu.au/

\section{Citation:}

Osman, N, Getachew, A, Burch, M, Lancaster, G, Wang, R, Wang, H, Zheng, W and Little AM, P 2011, 'TGF- $\beta$ stimulates biglycan core protein synthesis but not glycosaminoglycan chain elongation via Akt phosphorylation in vascular smooth muscle', Growth Factors, vol. 29 , no. 5, pp. 203-210.

See this record in the RMIT Research Repository at:

http://researchbank.rmit.edu.au/view/rmit:23353

Version: Accepted Manuscript

Copyright Statement: (c) 2011 Informa UK, Ltd

Link to Published Version:

http://dx.doi.org/10.3109/08977194.2011.615747 


\title{
TGFß stimulates biglycan core protein synthesis but not
}

\author{
glycosaminoglycan chain elongation via
}

Akt phosphorylation in vascular smooth muscle

Narin Osman ${ }^{\mathrm{a}}$, Robel Getachew ${ }^{\mathrm{a}}$, Micah Burch ${ }^{\mathrm{a}, \mathrm{b}}$ Graeme Lancaster $^{\mathrm{b}}$, Rikang Wang ${ }^{\mathrm{c}}$, Haitau Wang $^{\mathrm{c}}$, Wenhua Zheng ${ }^{\mathrm{c}}$, and Peter J. Little ${ }^{\mathrm{a}}$

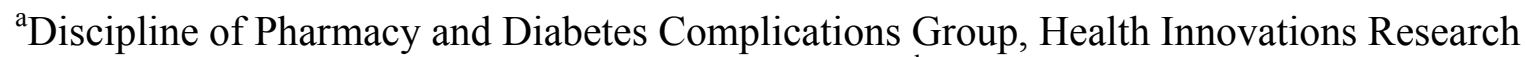
Institute, RMIT University, Bundoora, VIC Australia ${ }^{b}$ Cellular and Molecular Metabolism Laboratory, Baker IDI Heart \& Diabetes Institute, Melbourne, VIC, Australia, ${ }^{c}$ Neuropharmacology, School of Pharmaceutical Sciences, Sun Yat-Sen University, Guangzhou, Guangdong, China

*Corresponding author. Narin Osman, Discipline of Pharmacy and Diabetes Complications Group, Health Innovations Research Institute, RMIT University, Bundoora, VIC Australia Tel: 6139925 6686. Fax: 6139925 7063. Email address: narin.osman@rmit.edu.au

Keywords Akt, biglycan, transforming growth factor beta, atherosclerosis 


\begin{abstract}
Transforming growth factor $\beta$ (TGF- $\beta$ ) can mediate proteoglycan synthesis via Smad and nonSmad signalling pathways in vascular smooth muscle. We investigated whether TGF- $\beta$ mediated proteoglycan synthesis is via PI3K/Akt. TGF- $\beta$ induced a rapid phosphorylation of Akt that continued up to 4h. Akt phosphorylation was blocked by Akt1/2 inhibitor SN30978 however it did not block Smad2 phosphorylation at either the carboxy or linker regions indicating that TGF- $\beta$-mediated Akt phosphorylation is independent of Smad2 signalling. The role of Akt in TGF- $\beta$-mediated proteoglycan synthesis was investigated. Treatment with SN30978 showed a concentration-dependent decrease of TGF- $\beta$-mediated $\left[{ }^{35} \mathrm{~S}\right]$-sulfate and $\left[{ }^{35} \mathrm{~S}\right]-$ Met/Cys incorporation into secreted proteoglycans however SDS-PAGE showed no change in biglycan size. In TGF- $\beta$ treated cells biglycan mRNA levels increased by $40-100 \%$ by $24 \mathrm{~h}$ and was significantly blocked by SN30978. Our findings demonstrate that Akt is a downstream signalling component of TGF- $\beta$-mediated biglycan core protein synthesis but not glycosaminoglycan chain hyperelongation in vascular smooth muscle.
\end{abstract}




\section{Introduction}

Proteoglycans including biglycan accumulate in the extracellular matrix of atherosclerotic-prone artery walls in the early stages of atherosclerotic lesion development ${ }^{1}$. Biglycan is synthesized predominantly by vascular smooth muscle cells (VSMCs) in the vessel wall and atherogenic lipoproteins (LDL) become trapped on the negatively charged covalently attached glycosaminoglycan (GAG) chains thereby exacerbating macrophage accumulation and progression of atherosclerotic lesions. Previously it has been demonstrated that transforming growth factor- $\beta$ (TGF$\beta)$ treatment of human VSMCs increases the expression of biglycan and causes marked elongation of its GAG chains with a subsequent increase in the binding of $\mathrm{LDL}^{2,3,4,5}$. In addition TGF- $\beta$-mediated GAG elongation on biglycan requires de novo protein transcription and translation ${ }^{6}$.

TGF- $\beta$ signals via TGF- $\beta$ receptors type I and type II (T $\beta$ RI and T $\beta$ RII) with ligand binding causing the formation of a heteromeric complex of T $\beta R I$ and T $\beta R I I$ and resulting in the autophosphorylation and activation of T $\beta R I^{7}$. T $\beta R I$ then phosphorylates Smad2 and Smad3 in their C-terminal region which enables heterocomplex formation with Smad4 and subsequent translocation to the nucleus where they act as transcription factors binding to TGF- $\beta$ responsive genes ${ }^{8,9}$. The canonical TGF- $\beta$-mediated Smad2/3 C-terminal phosphorylation is important in many TGF- $\beta$ responses including biglycan synthesis and GAG chain elongation in VSM ${ }^{4}$. However it has also been established that TGF- $\beta$ can mediate pathways other than the canonical Smad pathway to generate proteoglycan synthesis. TGF- $\beta$-mediated phosphorylation of Smad2 linker region, described in the literature as a non-Smad pathway despite the integral role of Smad, has been shown to lead to activation of the 
ERK and p38 MAP kinase signalling pathways and results in biglycan synthesis and GAG elongation in human VSMCs ${ }^{2}$. In other contexts TGF- $\beta$-mediated phosphorylation of Smad linker region involves ERK and JNK MAP kinases ${ }^{10}$ however in VSMCs TGF- $\beta$ causes JNK phosphorylation without effect on proteoglycan synthesis $^{2}$.

Recently TGF- $\beta$ signalling has been shown to involve Akt via activation of the PI3KAkt-TOR-S6 kinase pathway in cells undergoing epithelial to mesenchymal transition 11. This activation has been shown to be independent of $\operatorname{Smad} 2 / 3$ in fibroblasts ${ }^{12}$. Akt, also referred to as $\mathrm{PKB}$, plays a key role in regulating cell survival and apoptosis 13,14. This protein kinase is activated by insulin and various growth factors in a wortmannin-sensitive pathway involving PI3 kinase ${ }^{14}$. Akt binds phospholipid and is activated by phosphorylation by PDK1 at Thr308 in the activation loop and by PDK2 at Ser473 at the carboxy terminus ${ }^{15}$. Akt inhibits apoptosis by phosphorylating and inactivating $\mathrm{Bad}^{16}$, forkhead transcription factors ${ }^{17}, \mathrm{c}$-Raf ${ }^{18}$ and caspase-9. Akt also regulates glycogen synthesis through phosphorylation and inactivation of GSK-3 $\alpha$ and $\beta^{19}$. In cell cycle regulation Akt prevents GSK-3 $\beta$ mediated phosphorylation and degradation of cyclin D1 ${ }^{20}$ and negatively regulates the cyclin dependent kinase inhibitors $\mathrm{p} 27 \mathrm{Kip}^{21}$ and $\mathrm{p} 21 \mathrm{Waf1/CIP} 1^{22}$. Akt also plays a critical role in cell growth by directly phosphorylating mTOR and tuberin (TSC2), an inhibitor of mTOR, in a rapamycin-sensitive complex containing raptor ${ }^{23}$. Inhibition of mTOR blocks protein synthesis and translation ${ }^{24}$.

Clearly Akt has key roles in EMT, cell cycle regulation, cell growth and cell survival in many cell types. TGF- $\beta$-mediated activation of PI3K/Akt pathway can complement 
or antagonize Smad-mediated effects depending on cell type and context. In this study we have investigated whether TGF- $\beta$ can activate Akt and its requirement for Smad in biglycan synthesis in human VSMCs.

\section{Materials and methods}

\section{Materials}

The following chemicals were purchased from Sigma, (St Louis, MO, USA): benzamidine hydrochloride, DEAE-Sephacel, Sepharose CL-6B, proteinase K, chondroitin sulfate, SB431542, PDGF, thrombin and penicillin-streptomycin. Recombinant TGF- $\beta 1$ was from R\&D Systems Inc. (Minneapolis, USA). SN30978 was a kind gift from Dr. Graeme Lancaster (BakerIDI, Melbourne, Australia). Dulbecco's modified eagle medium (DMEM), glutamine, fetal bovine serum (FBS) were purchased from Invitrogen. Rainbow $\left[{ }^{14} \mathrm{C}\right]$ methylated protein molecular weight standards (Amersham Pharmacia, Buckinghamshire, England). Cetyl pyridinium chloride (CPC) was from Unilab Chemicals and Pharmaceuticals, India. Whatman 3MM chromatography paper was from Biolab (Mulgrave, Australia), Instagel Plus scintillation fluid, $\left[{ }^{35} \mathrm{~S}\right]$ Sulfate and $\left[{ }^{35} \mathrm{~S}\right]-$ Met/Cys were from Perkin-Elmer (Waltham, MA, USA) and Poly-Prep columns from Bio-Rad (Hercules, CA USA)..

\section{Culture of human VSMC}

Human VSMCs were prepared by the explant method as previously described ${ }^{25}$ using otherwise discarded sections of the internal mammary artery and saphenous veins from patients undergoing coronary artery bypass grafting at Alfred Health, Melbourne, Australia. The acquisition of the vessel segments was approved by the Alfred Hospital Ethics committee. VSMC were grown in Dulbecco's modified eagle medium (DMEM) with 5mM glucose, 10\% FBS and 1\% penicillin-streptomycin 
solution. For experimentation, VSMC were seeded into 24 well plates (proteoglycan experiments) or $60 \mathrm{~mm}$ diameter plates (Western blotting experiments), grown until confluency then serum starved $(0.1 \%$ FCS $)$ for $48 \mathrm{~h}$ before experimentation as described.

\section{Western blotting}

Total cell lysates were resolved on 10\% SDS-PAGE and transferred onto PVDF membranes. Membranes were blocked with 5\% skim milk powder, incubated with primary antibodies as detailed in the text followed by HRP-anti-rabbit IgG and ECL detection (Amersham). Blots were quantified by densitometry using QuantityOne software (BioRad). Primary antibodies used in this study were anti-phosphoSmad2/3C rabbit monoclonal antibody, anti-phosphoSmad2L, antibody anti-phosphoAkt (phosphoThr308) antibody, anti-Akt1/2/3 antibody, anti-GAPDH antibody (Cell Signaling Technology, MA, USA)

\section{Quantitation of proteoglycan synthesis}

Quiescent cells were changed to fresh medium containing $25 \mu \mathrm{Ci} / \mathrm{mL}$ of $\left[{ }^{35} \mathrm{~S}\right]$ sulfate in the presence or absence of TGF- $\beta 1$ for 24 hours. Media from the cell cultures was harvested with added protease inhibitors (5mM Benzamidine in 0.1M 6-aminocaproic acid). Incorporation of the radiolabel into proteoglycans was measured by CPC precipitation assay as described previously ${ }^{26}$.

\section{SDS-PAGE analysis of proteoglycan size}

Proteoglycans labelled with $\left[{ }^{35} \mathrm{~S}\right]$ sulfate or $\left[{ }^{35} \mathrm{~S}\right]-\mathrm{Met} / \mathrm{Cys}$ were prepared for SDSPAGE by isolation through DEAE sephacel anionic exchange mini columns. Samples 
were added to pre-equilibrated columns, then washed extensively with low salt buffer (8M Urea, 0.25M NaCl, $2 \mathrm{mM}$ disodium EDTA, 0.5\% Triton X-100). Proteoglycans were eluted with high salt buffer (8M Urea, $3 \mathrm{M} \mathrm{NaCl}, 2 \mathrm{mM}$ disodium EDTA, $0.5 \%$ Triton X-100) Aliquots $(25,000 \mathrm{cpm})$ were precipitated $(1.3 \%$ potassium acetate, $95 \%$ ethanol) and chondroitin sulfate was added as a cold carrier. Samples were resuspended in buffer (8M Urea, $2 \mathrm{mM}$ disodium EDTA, $\mathrm{pH} 7.5)$, to which an equal volume of sample buffer was added. Radiolabelled proteoglycans were separated on $4-13 \%$ acrylamide gels with a $3 \%$ stacking gel at $50 \mathrm{~V}$ overnight. $\left[{ }^{14} \mathrm{C}\right]$-protein molecular weight markers were run simultaneously. Processed and dried gels were exposed to a phosphoimaging screen (Fuji Photo Film Co, Japan) for approximately 3 days, then scanned on a Bio-imaging analyser BAS-1000 MacBas (Fuji Photo Film Co, Japan).

Determination of the expression of biglycan by RT-PCR

Human VSMCs cells were plated on 6-well culture plate pre-coated with $10 \mathrm{ug} / \mathrm{ml}$ poly-D-lysine and fed with DMEM medium supplemented with 1\% FBS, plus antibiotics in $5 \% \mathrm{CO} 2$ at $37^{\circ} \mathrm{C}$. The following day medium was replaced with DMEM alone for $1 \mathrm{~h}$ then the cells were treated with TGF $\beta(2 \mathrm{ng} / \mathrm{ml})$ for different times as indicated to observe the effect of TGF $\beta$ on the expression of biglycan. In experiments using inhibitors, cells were pre-incubated with or without SN30978 $(5 \mu \mathrm{M})$ or SB431542 $(3 \mu \mathrm{M})$ for 30min, and then treated with TGF- $\beta(2 \mathrm{ng} / \mathrm{ml})$ for 24 hours. Total RNAs were extracted from treated cells using TRIZOL Reagent (TIANGEN Corp.). First-strand cDNA was synthesized from $1.5 \mu \mathrm{g}$ total RNA with random primer and M-MLV RTase (Genecopoeia Corp.); Resulting cDNA were subjected to PCR amplification using specific primers (sense primer, 5'- 
CTCCTCCAGGTGGTCTATC-3'and antisense primer, 5'-

GCTGATGCCGTTGTAGTAG-3') for biglycan. Products of PCR were

electrophoresed on a $1.5 \%$ agarose gel.

\section{Statistical analyses}

Data was analysed for statistical significance using a 1-way analysis of variance (ANOVA) or a Student's paired t-test as stated. Results were considered statistically significant at $\mathrm{P}<0.05$ or better as stated.

\section{Results}

TGF- $\beta$ causes rapid phosphorylation of Akt in human VSMCs

To determine whether TGF- $\beta$ can elicit phosphorylation of Akt in VSMCs we treated serum-deprived human VSMCs with TGF- $\beta$ ( $2 \mathrm{ng} / \mathrm{ml})$ for $0-4 \mathrm{~h}$ and then probed a western blot of whole cell lysates with anti-pAkt antibody (Figure 1). TGF- $\beta$ mediated a rapid phosphorylation of Akt Ser473 within 5 mins (Figure 1A) and elevated levels were maintained up to $4 \mathrm{~h}$ (Figure 1B). Time-course western blots probed with antibody to pAkt Thr308 gave the same results (data not shown). PDGF $(50 \mathrm{ng} / \mathrm{ml})$ was used as a positive control because of its ability to phosphorylate Akt at both Ser473 and Thr308 in VSMCs within 5 mins and sustain elevated levels for several hours ${ }^{27}$.

TGF- $\beta$ activates PI3K which in turn phosphorylates Akt on Ser473 and phosphoinositide-dependent kinase 1 (PDK1) a signalling component downstream of PI3K phosphorylates Akt Thr308. Phosphorylation can be inhibited by the allosteric non-ATP competitive Akt1/2 inhibitor SN30978 ${ }^{28}$. Cells were treated for either 15 
min or $4 \mathrm{~h}$ with TGF- $\beta$ in the absence or presence of SN30978 (Figure $2 \mathrm{~A}$ ). Akt phosphorylation was completely blocked by a 30 min pre-incubation of SN30978 (2 $\mu \mathrm{M}$ ) at both treatment times (Figure 2A). Therefore TGF- $\beta$ activates PI3K signalling that leads to pAkt in VSMCs. Blocking T $\beta$ RI activity with its specific inhibitor SB431542 ${ }^{29}$ reduced pAkt levels to basal (Figure 2B) demonstrating the requirement for T $\beta$ RI upstream of Akt phosphorylation. Previously we have reported that both thrombin and PDGF mediated proteoglycan core protein synthesis in VSMCs involve PI3K activity ${ }^{30}$. To determine whether Akt is phosphorylated downstream of PDGF or thrombin activation we treated cells with PDGF for $1 \mathrm{~h}$ and observed a marked elevation of pAkt levels above basal indeed they were higher than the level generated by TGF- $\beta$ treatment (Figure $2 \mathrm{~B}$ ). Thrombin stimulation of pAkt was close to basal levels at this time point. When we pre-treated cells with SN30978 and stimulated with PDGF or thrombin there was minimal generation of pAkt (Figure 2B) suggesting that PI3K/Akt are downstream of all three agonists in VSMCs but to different extents.

\section{TGF- $\beta$-mediated Smad2 phosphorylation is independent of Akt stimulation}

Smad-independent TGF- $\beta$ signalling of PI3K has been reported in fibroblasts ${ }^{12}$ and here we investigated whether blocking phosphorylation of Akt would interfere with the known pathway of TGF- $\beta$ /carboxy terminal and linker region phosphorylation of Smad $2{ }^{2,4}$. TGF- $\beta$ induces T $\beta$ RI to directly phosphorylate the two distal serines of Smad C-terminal SSXS motif and indirectly cause MAP kinases to phosphorylate serine and threonine residues in Smad linker region ${ }^{8}$. Western blots using antipSmad2C showed a significant increase (4.6-fold) in pSmad2C levels following TGF$\beta$ treatment (Figure $3 \mathrm{~A}$ and $3 \mathrm{~B})$. PDGF and thrombin showed a small increase in pSmad2C levels above basal the latter similar to our published findings ${ }^{31}$. Blocking 
Akt phosphorylation had no effect on pSmad2C levels after stimulation with any of the agonists (Figure 3A). TGF- $\beta$ treatment increased the level of Smad2 linker region phosphorylation approximately 5-fold compared to a 2-fold or less increase after PDGF or thrombin stimulation respectively (Figure 3B). Similarly to pSmad2C we observed no change in the levels of pSmad2L when Akt phosphorylation was blocked with SN30978 (Figure 3B). The inability of the Akt inhibitor to block Smad phosphorylation indicates that neither carboxy nor linker region Smad2 phosphorylation are downstream of Akt and in this context are likely independent of PI3K activation.

\section{TGF- $\beta$ stimulates biglycan core protein synthesis via Akt}

To determine whether Akt is a component of TGF- $\beta$-mediated proteoglycan synthesis in human VSMCs we performed experiments with the Akt1/2 inhibitor SN30978 on radiolabelled $\left[{ }^{35} \mathrm{~S}\right]$-sulfate incorporation into proteoglycans in TGF- $\beta$ treated cells. Figure 4 shows cells treated with TGF- $\beta$ had a $2-3$-fold increase in $\left[{ }^{35} \mathrm{~S}\right]$-sulfate into secreted proteoglycans, in these cells predominantly biglycan, compared to controls. Treatment with SN30978 $(0-3 \mu \mathrm{M})$ showed a concentration-dependent decrease of TGF- $\beta$-mediated $\left[{ }^{35} \mathrm{~S}\right]$-sulfate incorporation into secreted proteoglycans (Figure 4A) with a maximal $41 \%$ decrease at $3 \mu \mathrm{M}$. The T $\beta \mathrm{RI}$ inhibitor SB $431542{ }^{29}$ was used as a positive control. SDS-PAGE of the secreted proteoglycans showed no change in the size of the biglycan band at any concentration of the Akt inhibitor (Figure 4B). While proteoglycan core protein size remains fixed, GAG chains can vary in length and are altered by a variety of growth factors ${ }^{6}$. The current findings show that Akt is not involved in TGF- $\beta$-mediated proteoglycan GAG chain hyperelongation. 
To assess changes in proteoglycan core protein synthesis we labelled proteoglycans with $\left[{ }^{35} \mathrm{~S}\right]-\mathrm{Met} / \mathrm{Cys}$ for $24 \mathrm{~h}$ and quantitated incorporated radiolabel in secreted proteoglycans. TGF- $\beta$ stimulated cells showed an increase of approximately $20 \%$ in $\left[{ }^{35} \mathrm{~S}\right]-\mathrm{Met} / \mathrm{Cys}$ incorporation compared to control (Figure 4C). Treatment of cells with SN30978 showed a dose-dependent decrease in TGF- $\beta$-mediated $\left[{ }^{35} \mathrm{~S}\right]-\mathrm{Met} / \mathrm{Cys}$ incorporation with the level close to basal amounts at the maximal concentration tested (Figure 4C). To specifically examine biglycan core protein expression we measured the levels of biglycan mRNA in TGF- $\beta$ treated VSMCs. Biglycan mRNA levels increased over $24 \mathrm{~h}$ from an increase of 1.75 -fold at $3 \mathrm{~h}$ to a maximum of 2 -fold at 24h (Figure 5). In the presence of SN30978 there was a significant block of TGF- $\beta$ mediated increase of biglycan mRNA (Figure 6 , TGF- $\beta, 24 \mathrm{~h}$ ) which verifies that Akt is a downstream mediator of TGF- $\beta$-stimulated biglycan core protein synthesis in VSMCs.

\section{Discussion}

TGF- $\beta$ is a potent regulator of extracellular matrix synthesis including proteoglycan synthesis in the blood vessel wall ${ }^{2,3,4,5,32}$. In vascular smooth muscle TGF- $\beta$ upregulates biglycan expression and hyperelongation of its chondroitin sulfate GAG chains leading to increased binding to LDL with consequent increased lipid retention and accelerated atherosclerosis ${ }^{5,33}$. The signalling pathways from TGF- $\beta$ to the synthesis of proteoglycans are only partially described and are cell and context dependent. In this study we examined whether TGF- $\beta$-mediated activation of the PI3K/Akt pathway in human VSMCs and to what extent the pathway is involved in proteoglycan synthesis. We demonstrated that TGF- $\beta$ stimulated Akt phosphorylation within 5 mins and continued for at least 24h (see Figure 1) comparable to the response 
observed recently in cardiac fibroblasts ${ }^{34}$. TGF- $\beta$ mediates a slower time course of Akt phosphorylation in hypoxic pulmonary artery smooth muscle cells ${ }^{35}$, mesangial cells ${ }^{36}$ and fibroblasts ${ }^{37}$ and reflects the different cell contexts of TGF- $\beta$ signalling.

Our previous studies have shown that in VSMCs TGF- $\beta$ causes proteoglycan synthesis via both Smad-dependent ${ }^{4}$ and MAP kinase/Smad linker-dependent pathways ${ }^{2}$. Our results in the current study showed that blocking Akt phosphorylation did not alter the level of Smad2 phosphorylation at either the C-terminal SXSS motif or the linker region serine residues (see Figure 3) and Smad2 phosphorylation appears independent of PI3K/Akt activation. Our findings are in agreement with reports of TGF- $\beta$ regulating Smad 2 and Smad 3 and PI3K responses independently ${ }^{12}$. Other reports suggest the PI3K and Smad signalling pathways may be connected with Smad3 inhibition reducing TGF- $\beta$-mediated activation of $\mathrm{Akt}^{34}$ and PI3K inhibition decreasing Smad3 activity ${ }^{38}$. While we cannot ignore the possibility that Smad3 may signal differently to Smad2 our work has focussed on the latter transcription factor because to date we have no evidence to suggest a role for involvement of Smad3 in proteoglycan synthesis in VSMCs (unpublished observation). The exact mechanism of TGF- $\beta$ induced Akt phosphorylation in human VSMCs warrants further investigation.

Growth factor activation of the PI3K/Akt pathway upregulates extracellular matrix components including collagen via TGF- $\beta^{34}$ and proteoglycans via IGF $1^{39}$ and aggrecan and versican via IGF2 ${ }^{40}$ and GAG synthesis in fetal lung fibroblasts via PDGF $^{41}$. In VSMCs TGF- $\beta$ mediates proteoglycan synthesis via the Akt pathway (see Figure 4 ) as demonstrated by dose-dependently blocking $\left[{ }^{35} \mathrm{~S}\right]$-sulfate and $\left[{ }^{35} \mathrm{~S}\right]$ - 
Met/Cys incorporation into proteoglycans with SN30978. We determined that Akt signalling does not affect GAG synthesis as there is no detectable change in biglycan GAG length when this pathway is inhibited (Figure 4). Biglycan core protein synthesis is dependent on Akt phosphorylation demonstrated by the ability of the Akt inhibitor to block TGF- $\beta$ mediated increase in biglycan mRNA (see Figure 6) and incorporation of $\left[{ }^{35} \mathrm{~S}\right]-\mathrm{Met} / \mathrm{Cys}$ into core protein (see Figure 4). The T $\beta R I$ inhibitor SB431542 blocks proteoglycan chain elongation independently of core protein synthesis ${ }^{4}$. Here we saw SN30978 only able to block Akt-mediated biglycan core protein synthesis not chain elongation demonstrating that at least two signalling pathways may be involved in biglycan core protein synthesis. Interestingly in human chondrocytes IGF2 upregulates aggrecan and versican mRNA levels via Akt ${ }^{40}$ however IGF1 has no effect via Akt on aggrecan, decorin or biglycan core protein mRNA levels ${ }^{39}$. Similarly Akt signalling results in different outcomes in GAG synthesis with our results showing TGF-mediated phosphorylation of Akt not altering biglycan GAG synthesis but PDGF-mediated Akt activation reported to have an integral role in GAG regulation in fetal lung fibroblasts ${ }^{42}$. The diversity of effects suggests differences and complexity reflecting not only cell type but also the activating growth factor and its downstream outputs.

\section{Conclusions}

We have demonstrated that Akt is an active component of TGF-mediated signalling to biglycan core protein synthesis in human vascular smooth muscle cells. In contrast TGF- $\beta$-induced proteoglycan GAG chain hyperelongation does not require Akt phosphorylation. Akt signalling pathways are important in many cellular contexts and 
further investigations are warranted to determine whether Akt instigates changes in other proteoglycan related cellular processes and in other cell types.

\section{Acknowledgements}

This study was supported by National Heart Foundation of Australia grants-in-aid (PJL \& NO) and grants for Wenhua Zheng from National Natural Science Fund of China (No. 30711120565; No. 30970935).

\section{Declarations of Interest}

No conflicts of interest to declare.

\section{References}

1. Nakashima Y, Wight TN, Sueishi K. Early atherosclerosis in humans: role of diffuse intimal thickening and extracellular matrix proteoglycans. Cardiovasc Res. 2008;79: 14-23.

2. Burch ML, Yang SN, Ballinger ML, Getachew R, Osman N, Little PJ. TGFbeta stimulates biglycan synthesis via p38 and ERK phosphorylation of the linker region of Smad2. Cell Mol Life Sci. 2010;67: 2077-90. 3. Schonherr E, Jarvelainen HT, Kinsella MG, Sandell LJ, Wight TN. Plateletderived growth factor and transforming growth factor-beta 1 differentially affect the synthesis of biglycan and decorin by monkey arterial smooth muscle cells. Arterioscler Thromb. 1993;13: 1026-36.

4. Dadlani H, Ballinger ML, Osman N, Getachew R, Little PJ. Smad and p38 MAP kinase-mediated signaling of proteoglycan synthesis in vascular smooth muscle. J Biol Chem. 2008;283: 7844-52.

5. Little PJ, Tannock L, Olin KL, Chait A, Wight TN. Proteoglycans synthesized by arterial smooth muscle cells in the presence of transforming growth factorbeta1 exhibit increased binding to LDLs. Arterioscler Thromb Vasc Biol. 2002;22: 55-60.

6. Yang SN, Burch ML, Getachew R, Ballinger ML, Osman N, Little PJ. Growth factor-mediated hyper-elongation of glycosaminoglycan chains on biglycan requires transcription and translation. Arch Physiol Biochem. 2009;115: 147-54. 7. Bobik A. Transforming growth factor-betas and vascular disorders. Arterioscler Thromb Vasc Biol. 2006;26: 1712-20.

8. Derynck R, Zhang YE. Smad-dependent and Smad-independent pathways in TGF-beta family signalling. Nature. 2003;425: 577-84. 
9. Shi Y, Massague J. Mechanisms of TGF-beta signaling from cell membrane to the nucleus. Cell. 2003;113: 685-700.

10. Li F, Fan C, Cheng T, Jiang C, Zeng B. Efficient inhibition of fibroblast proliferation and collagen expression by ERK2 siRNAs. Biochem Biophys Res Commun. 2009;382: 259-63, Mori S, Matsuzaki K, Yoshida K, et al. TGF-beta and HGF transmit the signals through JNK-dependent Smad2/3

phosphorylation at the linker regions. Oncogene. 2004;23: 7416-29.

11. Lamouille $S$, Derynck $R$. Cell size and invasion in TGF-beta-induced epithelial to mesenchymal transition is regulated by activation of the $\mathrm{mTOR}$ pathway. J Cell Biol. 2007;178: 437-51, Das L, Levine AD. TGF-beta inhibits IL2 production and promotes cell cycle arrest in TCR-activated effector/memory $T$ cells in the presence of sustained TCR signal transduction. $J$ Immunol. 2008;180: 1490-8.

12. Wilkes MC, Mitchell H, Penheiter SG, et al. Transforming growth factorbeta activation of phosphatidylinositol 3-kinase is independent of Smad2 and Smad3 and regulates fibroblast responses via p21-activated kinase-2. Cancer Res. 2005;65: 10431-40.

13. Franke TF, Kaplan DR, Cantley LC. PI3K: downstream AKTion blocks apoptosis. Cell. 1997;88: 435-7.

14. Burgering BM, Coffer PJ. Protein kinase B (c-Akt) in phosphatidylinositol-3OH kinase signal transduction. Nature. 1995;376: 599-602, Franke TF, Yang SI, Chan TO, et al. The protein kinase encoded by the Akt proto-oncogene is a target of the PDGF-activated phosphatidylinositol 3-kinase. Cell. 1995;81: 72736.

15. Alessi DR, Andjelkovic M, Caudwell B, et al. Mechanism of activation of protein kinase B by insulin and IGF-1. EMBO J. 1996;15: 6541-51.

16. Cardone MH, Roy N, Stennicke HR, et al. Regulation of cell death protease caspase-9 by phosphorylation. Science. 1998;282: 1318-21.

17. Brunet A, Bonni A, Zigmond MJ, et al. Akt promotes cell survival by phosphorylating and inhibiting a Forkhead transcription factor. Cell. 1999;96: 857-68.

18. Zimmermann S, Moelling K. Phosphorylation and regulation of Raf by Akt (protein kinase B). Science. 1999;286: 1741-4.

19. Hajduch E, Litherland GJ, Hundal HS. Protein kinase B (PKB/Akt)--a key regulator of glucose transport? FEBS Lett. 2001;492: 199-203, Cross DA, Alessi DR, Cohen P, Andjelkovich M, Hemmings BA. Inhibition of glycogen synthase kinase-3 by insulin mediated by protein kinase B. Nature. 1995;378: 785-9.

20. Diehl JA, Cheng M, Roussel MF, Sherr CJ. Glycogen synthase kinase-3beta regulates cyclin D1 proteolysis and subcellular localization. Genes Dev. 1998;12: 3499-511.

21. Gesbert F, Sellers WR, Signoretti S, Loda M, Griffin JD. BCR/ABL regulates expression of the cyclin-dependent kinase inhibitor p27Kip1 through the phosphatidylinositol 3-Kinase/AKT pathway. J Biol Chem. 2000;275: 39223-30. 22. Zhou BP, Liao Y, Xia W, Spohn B, Lee MH, Hung MC. Cytoplasmic localization of p21Cip1/WAF1 by Akt-induced phosphorylation in HER-2/neuoverexpressing cells. Nat Cell Biol. 2001;3: 245-52.

23. Nave BT, Ouwens M, Withers DJ, Alessi DR, Shepherd PR. Mammalian target of rapamycin is a direct target for protein kinase $B$ : identification of a convergence point for opposing effects of insulin and amino-acid deficiency on protein translation. Biochem J. 1999;344 Pt 2: 427-31. 
24. Inoki K, Li Y, Zhu T, Wu J, Guan KL. TSC2 is phosphorylated and inhibited by Akt and suppresses mTOR signalling. Nat Cell Biol. 2002;4: 648-57, Manning BD, Tee AR, Logsdon MN, Blenis J, Cantley LC. Identification of the tuberous sclerosis complex-2 tumor suppressor gene product tuberin as a target of the phosphoinositide 3-kinase/akt pathway. Mol Cell. 2002;10: 151-62.

25. Neylon CB, Little PJ, Cragoe EJ, Jr., Bobik A. Intracellular pH in human arterial smooth muscle. Regulation by $\mathrm{Na}+/ \mathrm{H}+$ exchange and a novel 5-(N-ethyl$\mathrm{N}$-isopropyl)amiloride-sensitive $\mathrm{Na}(+)$ - and $\mathrm{HCO3(-)-dependent} \mathrm{mechanism.} \mathrm{Circ}$ Res. 1990;67: 814-25.

26. Nigro J, Dilley RJ, Little PJ. Differential effects of gemfibrozil on migration, proliferation and proteoglycan production in human vascular smooth muscle cells. Atherosclerosis. 2002;162: 119-29, Tannock L, Little PJ, Wight TN, Chait A. Arterial smooth muscle cell proteoglycans synthesized in the presence of glucosamine demonstrate reduced binding to LDL. J Lipid Res. 2002;43: 149-57. 27. Yellaturu CR, Bhanoori M, Neeli I, Rao GN. N-Ethylmaleimide inhibits platelet-derived growth factor BB-stimulated Akt phosphorylation via activation of protein phosphatase $2 \mathrm{~A}$. $J$ Biol Chem. 2002;277: 40148-55.

28. DeFeo-Jones D, Barnett SF, Fu S, et al. Tumor cell sensitization to apoptotic stimuli by selective inhibition of specific Akt/PKB family members. Mol Cancer Ther. 2005;4: 271-9.

29. Inman GJ, Nicolas FJ, Callahan JF, et al. SB-431542 is a potent and specific inhibitor of transforming growth factor-beta superfamily type $I$ activin receptorlike kinase (ALK) receptors ALK4, ALK5, and ALK7. Mol Pharmacol. 2002;62: 65-74.

30. Getachew R, Ballinger ML, Burch ML, et al. Platelet-Derived Growth Factor \{beta\}-Receptor Kinase Activity and ERK1/2 Mediate Glycosaminoglycan Elongation on Biglycan and Increases Binding to Low-Density Lipoprotein. Endocrinology. 2010;151: 4356 - 67.

31. Burch ML, Ballinger ML, Yang SN, et al. Thrombin stimulation of proteoglycan synthesis in vascular smooth muscle is mediated by proteaseactivated receptor-1 transactivation of the transforming growth factor beta type I receptor. $J$ Biol Chem. 2010;285: 26798-805.

32. Schonherr E, Jarvelainen HT, Sandell LJ, Wight TN. Effects of plateletderived growth factor and transforming growth factor-beta 1 on the synthesis of a large versican-like chondroitin sulfate proteoglycan by arterial smooth muscle cells. J Biol Chem. 1991;266: 17640-7.

33. Little PJ, Osman N, O'Brien KD. Hyperelongated biglycan: the surreptitious initiator of atherosclerosis. Current Opinion in Lipidology. 2008;19: 448-54.

34. Voloshenyuk TG, Landesman ES, Khoutorova E, Hart AD, Gardner JD. Induction of cardiac fibroblast lysyl oxidase by TGF-beta1 requires PI3K/Akt, Smad3, and MAPK signaling. Cytokine. 2011.

35. Ismail S, Sturrock A, Wu P, et al. NOX4 mediates hypoxia-induced proliferation of human pulmonary artery smooth muscle cells: the role of autocrine production of transforming growth factor-\{beta\} 1 and insulin-like growth factor binding protein-3. Am J Physiol Lung Cell Mol Physiol. 2009;296: L489-99.

36. Hubchak SC, Sparks EE, Hayashida T, Schnaper HW. Rac1 promotes TGFbeta-stimulated mesangial cell type I collagen expression through a PI3K/Aktdependent mechanism. Am J Physiol Renal Physiol. 2009;297: F1316-23. 
37. Rahimi RA, Andrianifahanana M, Wilkes MC, et al. Distinct roles for mammalian target of rapamycin complexes in the fibroblast response to transforming growth factor-beta. Cancer Res. 2009;69: 84-93.

38. Runyan CE, Schnaper HW, Poncelet AC. The phosphatidylinositol 3kinase/Akt pathway enhances Smad3-stimulated mesangial cell collagen I expression in response to transforming growth factor-beta1. $J$ Biol Chem. 2004;279: 2632-9.

39. Starkman BG, Cravero JD, Delcarlo M, Loeser RF. IGF-I stimulation of proteoglycan synthesis by chondrocytes requires activation of the PI 3-kinase pathway but not ERK MAPK. Biochem J. 2005;389: 723-9.

40. Hamamura K, Zhang P, Yokota H. IGF2-driven PI3 kinase and TGFbeta signaling pathways in chondrogenesis. Cell Biol Int. 2008;32: 1238-46.

41. Liu J, Fitzli D, Liu M, et al. PDGF-induced glycosaminoglycan synthesis is mediated via phosphatidylinositol 3-kinase. Am J Physiol. 1998;274: L702-13, Cartel NJ, Wang J, Post M. Platelet-derived growth factor-BB-mediated glycosaminoglycan synthesis is transduced through Akt. Biochem J. 2002;363: 19-28.

42. Carter AM, Grant PJ. Vascular homeostasis, adhesion molecules, and macrovascular disease in non-insulin-dependent diabetes mellitus. Diabet Med. 1997;14: 423-32. 


\section{Figure Legends}

Figure 1 Time-course of TGF- $\beta$ mediated phosphorylation of Akt in human VSMCs. Human VSMC were or untreated (-) or treated with TGF- $\beta$ ( $2 \mathrm{ng} / \mathrm{ml})$ for (A) 0 - 30 mins and (B) 0 - 360 mins. PDGF (50 ng/ml)-treated VSMCs were used as a positive control. Whole cell protein lysates were resolved by $10 \%$ SDS-PAGE gels and transferred to PVDF membranes. Membranes were probed with primary antiphospho-Akt (pAkt, Ser473) antibody and visualised with ECL. Blots were stripped and re-probed for total Akt (Akt) and GAPDH for loading controls.

Figure 2 Akt1/2 inhibitor completely blocks TGF- $\beta$ mediated phosphorylation of Akt.

Cells were untreated (-) or pre-treated for 30 min with the Akt1/2 inhibitor SN30978 $(2 \mu \mathrm{M})$ and then stimulated with (A) TGF- $\beta(2 \mathrm{ng} / \mathrm{ml})$ for either $15 \mathrm{~min}$ or $4 \mathrm{~h}$, or PDGF (50 ng/ml) for $1 \mathrm{~h}(\mathrm{~B})$ Thrombin (10 Units/ml), PDGF (50 ng/ml) or TGF- $\beta$ (2 $\mathrm{ng} / \mathrm{ml}$ ) for $1 \mathrm{~h}$. Cells pre-treated for $30 \mathrm{~min}$ with T $\beta \mathrm{RI}$ kinase inhibitor SB431542 (3 $\mu \mathrm{M})(\mathrm{SB})$ were stimulated with TGF- $\beta$ ( $2 \mathrm{ng} / \mathrm{ml})$ for $1 \mathrm{~h}$. Cell lysates were processed and probed for phospho-Akt, Akt and GAPDH as described. Density analysis using Biorad Quantity One software is shown to the right of each blot, \#\# $\mathrm{P}<0.01$ vs control, ** $\mathrm{P}<0.01$ vs agonist, $\# \mathrm{P}<0.05$ vs control

\section{Figure 3 Role of Akt in TGF- $\beta$-mediated Smad pathway}

Cells were untreated (-) or pre-treated for 30 min with the Akt1/2 inhibitor SN30978

$(2 \mu \mathrm{M})$ and then stimulated with Thrombin (10 Units/ml), PDGF (50 ng/ml) or TGF- $\beta$

(2 $\mathrm{ng} / \mathrm{ml}$ ) for $1 \mathrm{~h}$. Cells pre-treated for $30 \mathrm{~min}$ with T $\beta R I$ kinase inhibitor SB431542

$(3 \mu \mathrm{M})(\mathrm{SB})$ were stimulated with TGF- $\beta(2 \mathrm{ng} / \mathrm{ml})$ for $1 \mathrm{~h}$. Cell lysates were 
processed as described (see Figure 1 legend) and probed with (A) anti-phosphoSmad2 carboxy terminal antibody (pSmad2C) or (B) anti-phospho-Smad2 linker region antibody (pSmad2L) and GAPDH. Density analysis using Biorad Quantity One software is shown for each blot (B) pSmad2C and (C) pSmad2L, \#\# P<0.01 vs control, $* * \mathrm{P}<0.01$ vs agonist.

Figure 4 Role of Akt in TGF- $\beta$-mediated proteoglycan synthesis in human VSMCs.

VSMCs were pre-treated for 30 min with SN30978 $(0-3 \mu \mathrm{M})$ or SB431542 $(3 \mu \mathrm{M})$ (SB) and then stimulated with TGF- $\beta(2 \mathrm{ng} / \mathrm{ml})$ for $24 \mathrm{~h}$ in the presence of $\left[{ }^{35} \mathrm{~S}\right]-$ sulfate or $\left[{ }^{35} \mathrm{~S}\right]-\mathrm{Met} / \mathrm{Cys}$ for $24 \mathrm{~h}$. (A) $\left[{ }^{35} \mathrm{~S}\right]$-sulfate incorporation (B) SDS-PAGE analysis of $\left[{ }^{35} \mathrm{~S}\right]$-sulfate incorporated samples $(\mathrm{C})\left[{ }^{35} \mathrm{~S}\right]$-Met/Cys incorporation into proteoglycan core protein synthesis. Histogram values are expressed as percentage of untreated control value, \#\# $\mathrm{P}<0.01$ vs control, ${ }^{* *} \mathrm{P}<0.01$ vs agonist.

Figure 5 TGF- $\beta$-induced changes in biglycan mRNA levels in human VSMCs. Human VSMCs were treated with TGF- $\beta$ ( 2 ng.ml) for various times $(0-24$ h), and the expressions of biglycan were determined by RT-PCR as described in Material and Method. RPL is ribosomal protein mRNA. TGF- $\beta$ time-dependently induced the expression of biglycan in human VSMCs cells. The relative mRNA level was normalised to the level of untreated control cells. \#\# $\mathrm{P}<0.01$ vs control. Results are from four independent experiments.

Figure 6 Effects of Akt inhibitor SN30978 on biglycan mRNA levels. 
VSMCs pre-treated with or without SN30978 $(5 \mu \mathrm{M})$ or SB431542 $(3 \mu \mathrm{M})$ for $30 \mathrm{~min}$ were stimulated with TGF- $\beta$ ( 2 ng.ml) for $24 \mathrm{~h}$, and levels of biglycan mRNA measured. Both SN30978 and SB431542 blocked TGF- $\beta$-induced expression of biglycan in VSMCs. The relative mRNA level was normalised to the level of untreated control cells (-). ${ }^{* *} \mathrm{P}<0.01$ vs agonist, ${ }^{*} \mathrm{P}<0.05$ vs agonist, $\# \mathrm{P}<0.05$ vs control. Results are from three independent experiments. 
A

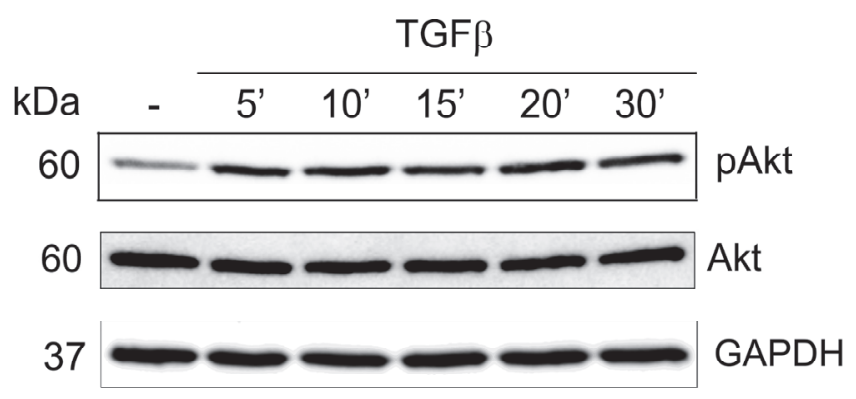

B

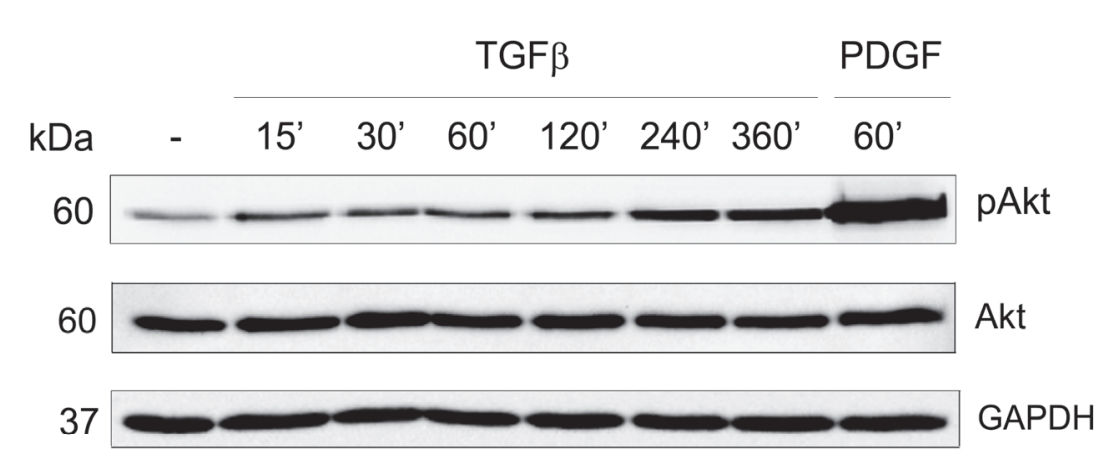



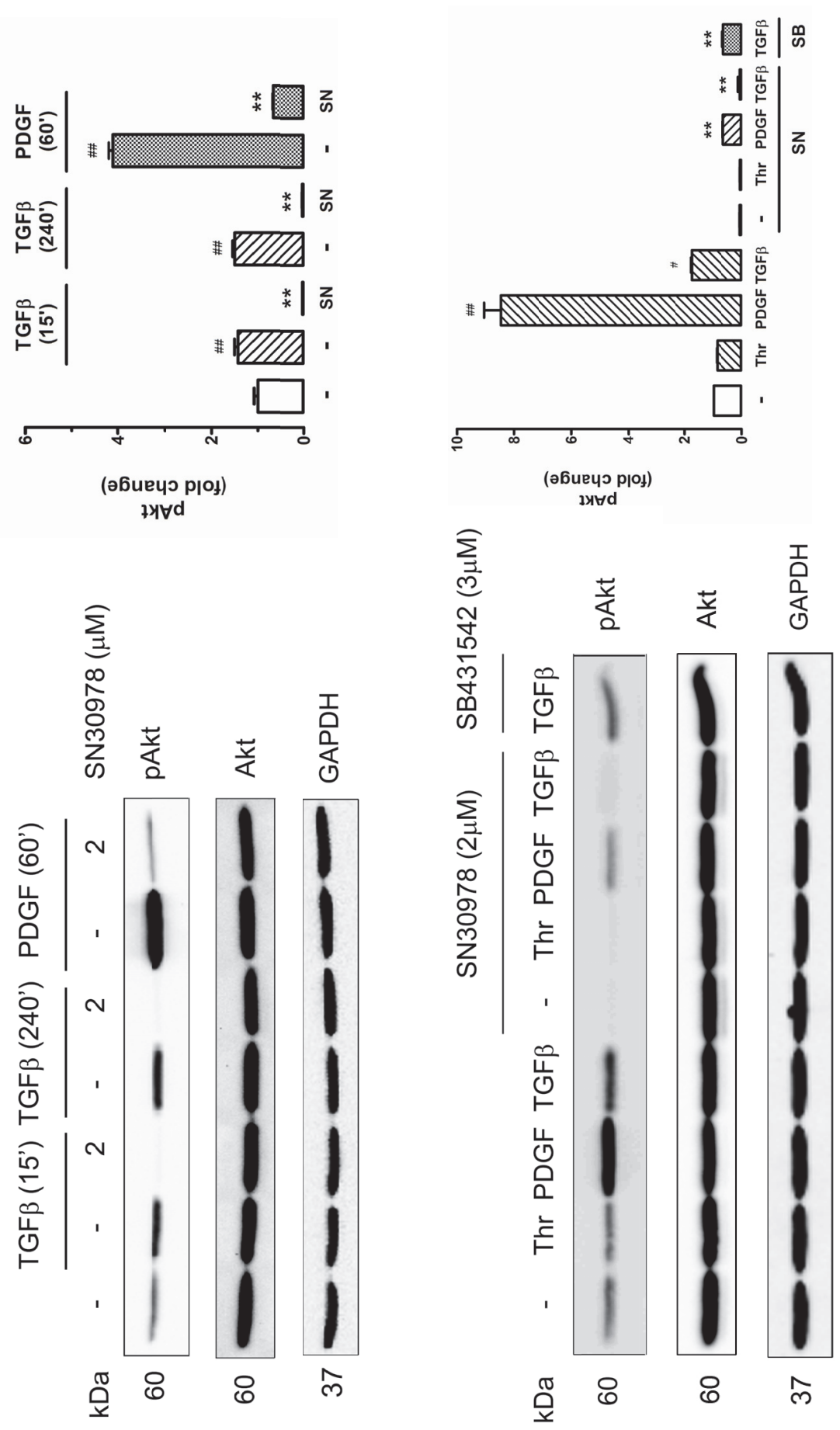

A

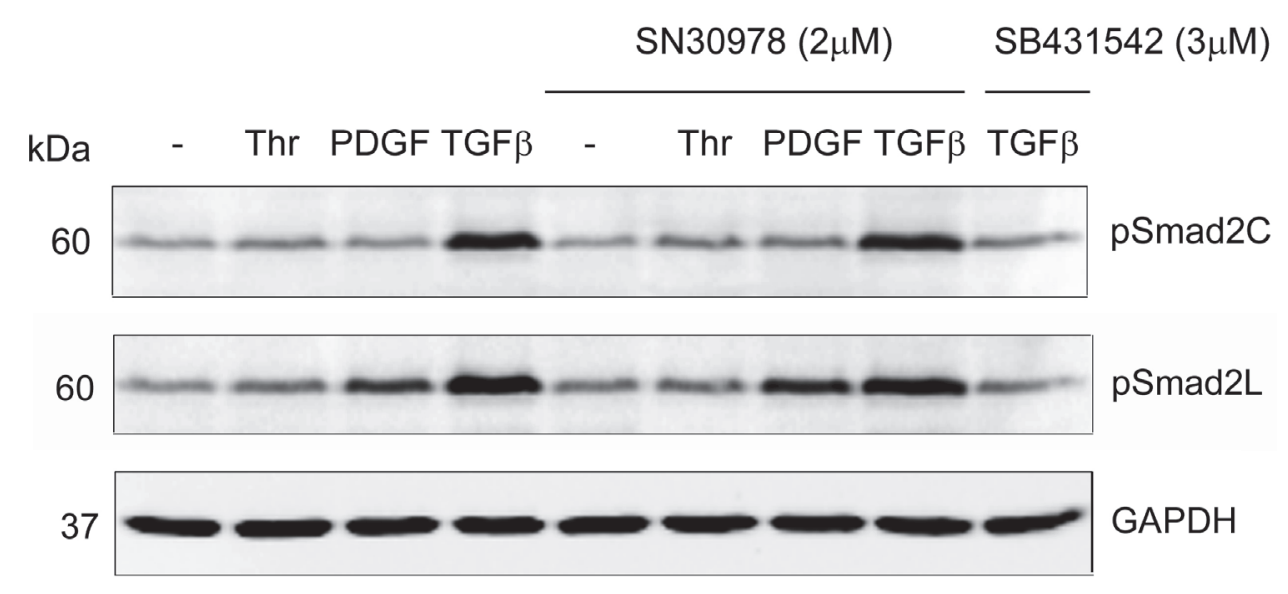

B

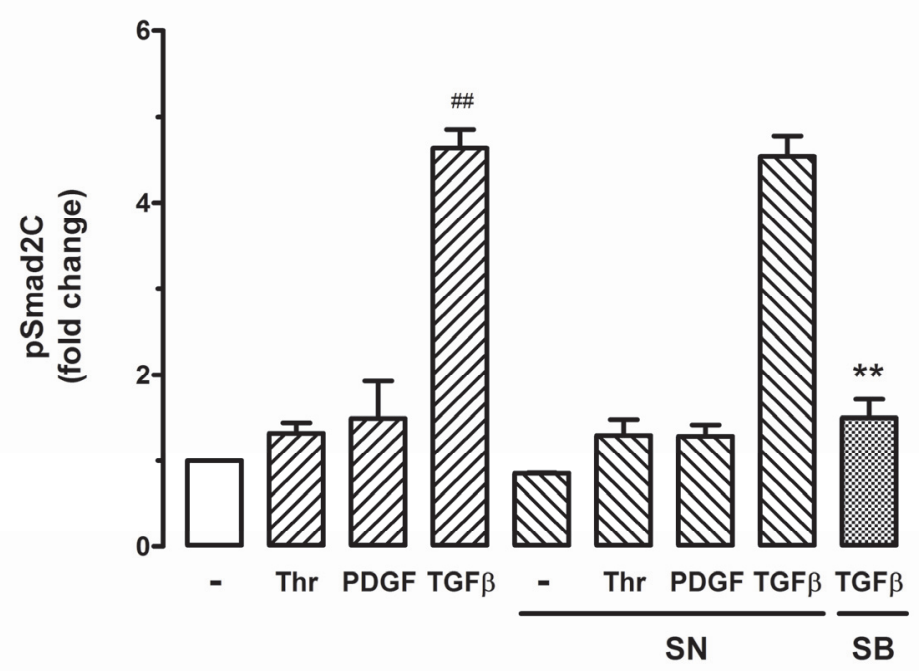

C

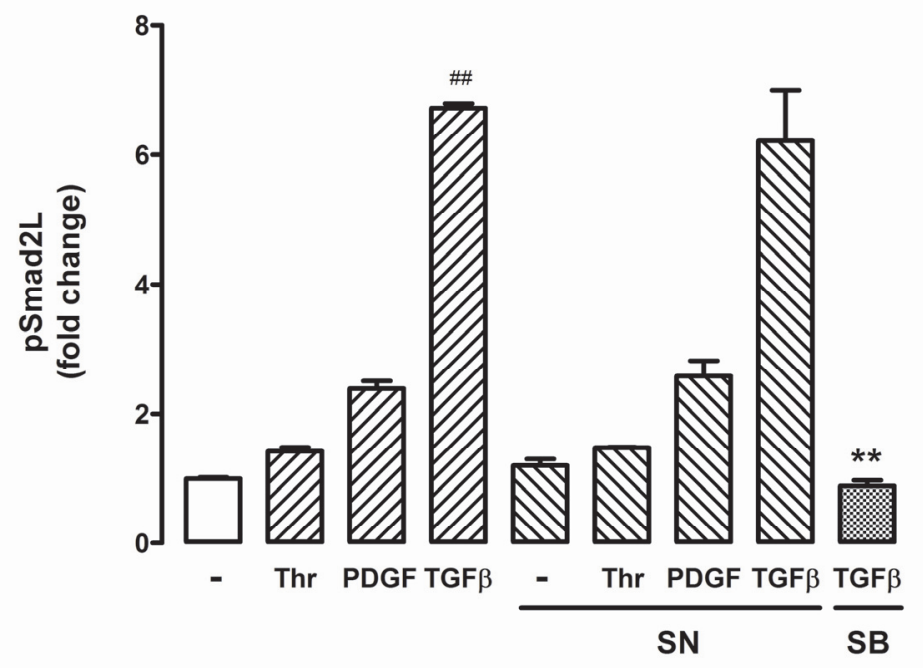


A

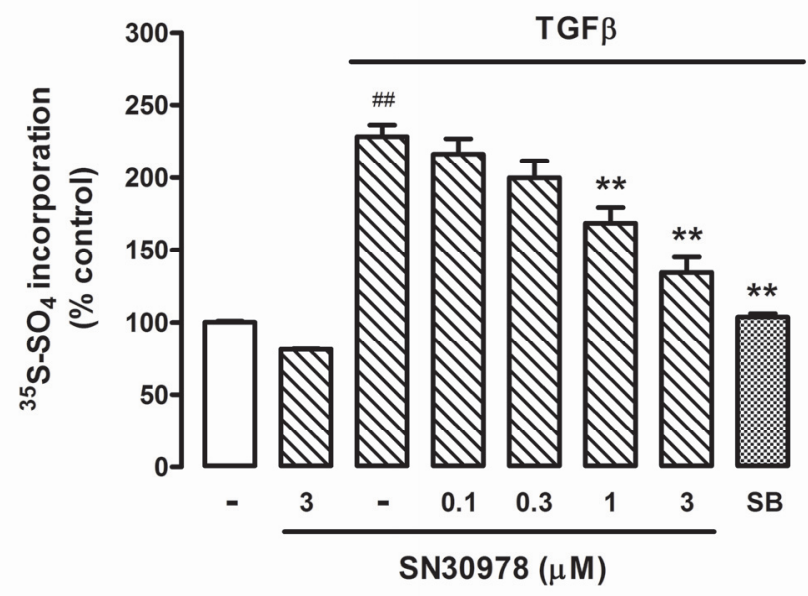

B

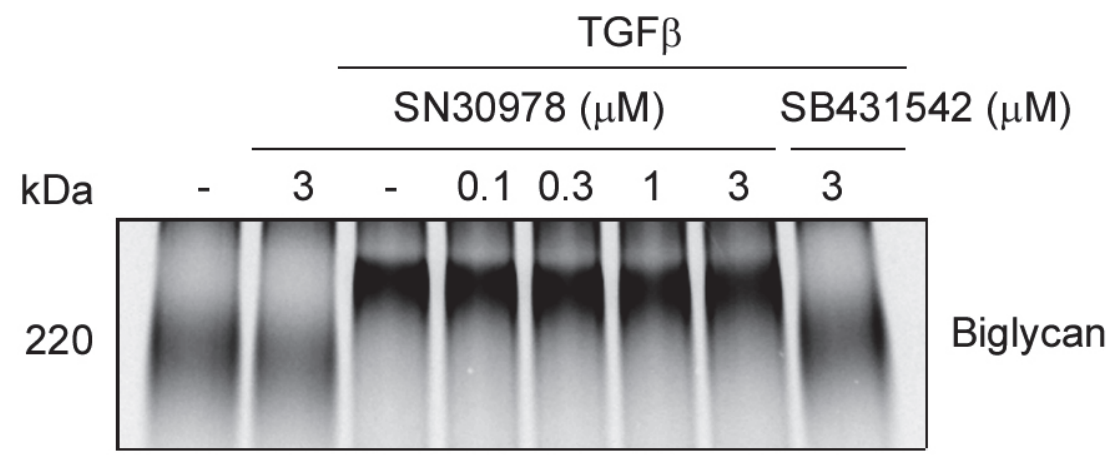

C

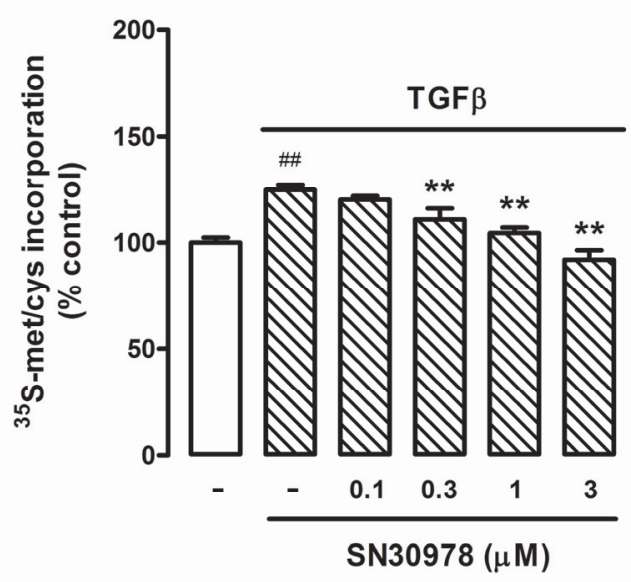




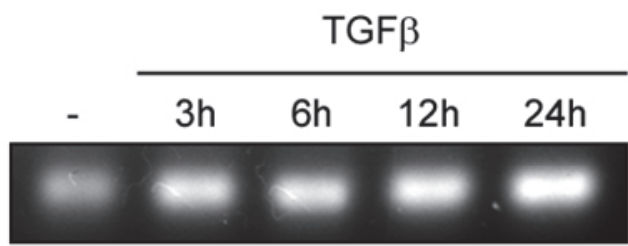

RPL-19

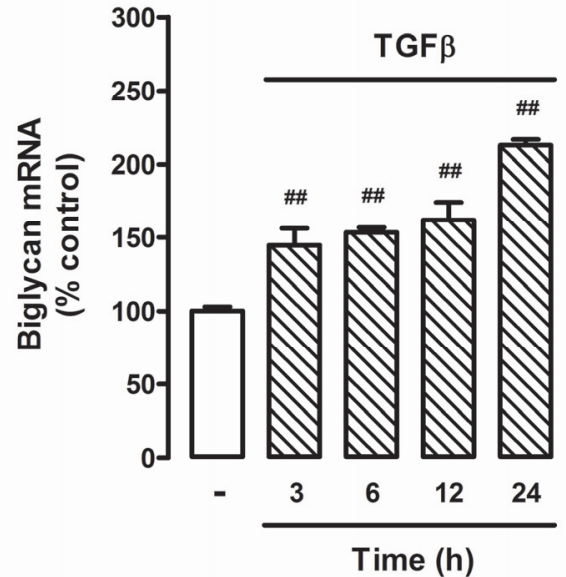



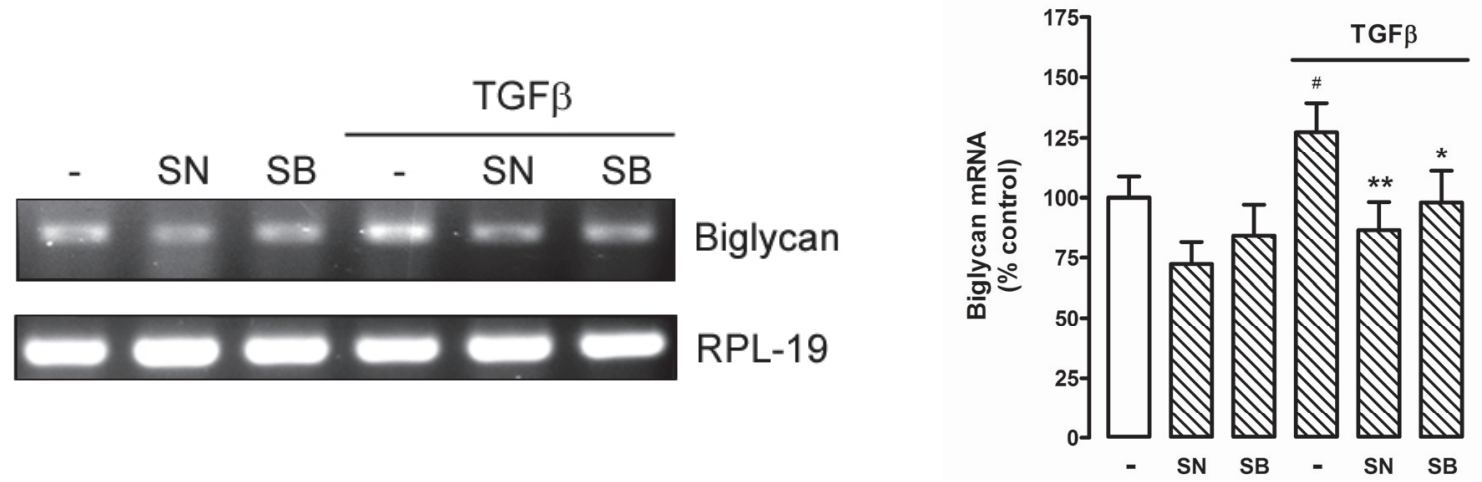